www.jmscr.igmpublication.org

Impact Factor 5.244

Index Copernicus Value: 5.88

ISSN (e)-2347-176x ISSN (p) 2455-0450

crossref DOI: _http://dx.doi.org/10.18535/jmscr/v4i5.20

Journal Of Medical Science And Clinical Research

IGM Publication

An official Publication of IGM Publication

\title{
Distribution of Super Antigensgene of Staphylococcus aureus in Allergic Rhinitis Patients
}

\author{
Authors \\ Thanaa Shams Al-deen AL-Turaihi, Prof Dr Kareem Thamir Al-Kaabi \\ Corresponding Author \\ Thanaa Shams Al-deen AL-Turaihi Lecturer \\ Department of Medical Microbiology, Kufa College of Medicine \\ Ph.D Student in Kufa College of Medicine Department of Medical Microbiology
}

Email: thanaa.shams@yahoo.com

Summary Staphylococcus aureus is a representative constituted pathogen related with the major community and hospital acquired sickness and has been taken into consideration for a long time as a major problem of Public Health,Several virulence factors engaged in the pathogenesis of S. aureus strains Perhaps the most notable virulence factors associated with this microorganism are the heat-stable enterotoxins that cause the sporadic food-poisoning syndrome or foodborne outbreaks (Martin et al.,2003).

Hypothesis: The pathogenesis of Allergic rhinitis(AR) has been a hot subject, recent studies had suggested that Staphylococcus aureus excretes exotoxins that may act as superantigens and can influence the activity of both immune modulatory and pro inflammatory effector cell type and therefore, may have a potentially important role in the pathogenesis of chronic inflammatory disease or lead to exacerbation of upper airway disease

Methodology A case -control study has been conducted to determine the prevalence of enterotoxin producing Staphylococcus aureus in the nasal cavities of patients with allergic rhinitis during the period from March 2014 to November 2014, 100 patients with Allergic rhinitis and 100 control subjects, the patients attended AlSadder Medical City, outpatient clinic of ENT in Najaf city. For isolation of S. aureus, a nasal swab was taken from each of the 100 patients and 100 controls by using a sterile cotton swab. Isolates were identified by a conventional test and then confirmed by Biomerieux Vitek 2 Compact Automated Microbial Identification. The super antigen genes (SEA, SEB,SEC,SED,SEE, and TSST) were detected by using conventional PCR on the isolate then an enzyme immune assay RIDASCREEN ${ }^{\circledR}$ SET A, B,C,D,Epreformed on broth culture of these isolates in order to identify the enterotoxins production or libration.

Result: Nasal S. aureus carriage was significantly more frequent in patients with allergic rhinitis than in nonallergic controls $(P<0.001),(O d d s=3.4306 C I=1.8-6.26)$. The distribution of toxigenic $S$. aureus that recover from allergic rhinitis patients by PCR test was (63.16\%) and (26.32\%) from control groups and the difference was non-significant $P=0.434$. The most frequently detected enterotoxin was staphylococcal enterotoxin $B$ (SEB).ELISA test seem to be more sensitive for (SED, SEC, and SEE) and less sensitive for (SEA and SEB), however the specificity of ELISA is better in (SEB, SEC, SED, SEE than SEA

Conclusion: We have demonstrated that the rate of nasal carriage of Staphylococcus aureus in allergic rhinitis patients was significantly higher than that of control subject,-Staphylococcus aureus isolated from allergic rhinitis patients have a probably a relationship with the disease and their superantigen have been a role in triggering and exacerbation of the disease

Keyword; Allergic rhinitis, Staphylococcus aureus, Superantigens 


\section{Allergic Rhinitis}

Allergic rhinitis (AR) is a disease that is a chronic airway inflammatorycondition with the eosinophilic cell as a responseto aninhalant allergic material in geneticallyliablepatients (Liu et al., 2014).

The following are the predominant symptom of the AR patients: sneezing, nasal itching, congestion, of the nasal mucosa and running nose (Al-Abri et al .,2014) another organ of the body (nearby organs) are also involved which are the eyes, ears, sinuses, and throat, the smell sense can also be affected if the disease is for a prolong period (Guilemany,2009).

\section{Epidemiology}

Allergic Rhinitis is a global health problem that affects $20 \%-40 \%$ of the population in developed countries and whose incidence is rising. It can be induced by different mechanisms and involves several etiological agents (Rondon et al.,2007).

\section{Staphylococcus aureus}

Staphylococci are sphericalin shape and grampositivebacteria which are non motile and do not form spores (Murray et al., 2003).

Staphylococcus aureus isan important human pathogensespecially in hospital-acquired infections (Guidey et al, 2014) and also in community-acquired infections, with methicillinresistant S. aureus (MRSA) having a considerable public health threat.(Liu et al.,2009) S. aureus have the property to colonize asymptomatically healthy individuals. The carriers are at higher risk of infection, and they are considered as an important origin of the $S$. aureus strains that spread among other individual (Chambers \&DeLeo.,2009).

Some are considered to be part of the normal flora (normal inhabitant) lives within the body, colonizing the skin and mucous membranes in 10 to $20 \%$ of healthy adults of humans and also in the nose of a healthy human (Lowy, 1998).

They can be a causative agent of different superficial and deep infections, where pus was formed in many times in human. Occasionally, $S$. aureus is regarded as an opportunistic pathogens as in case of infections of the urinary tract, respiratory tract, and gastrointestinal tract.The most commonly affected area of the bodybecause of S. aureus infection is the skin (Daum, 2007). However, nasal colonization increases the risk of infection byfour-fold (Safdar \& Bradley, 2008).

Superantigens: enterotoxins and toxic shock syndrome toxin

Two types of staphylococcal toxins are having superantigenactivity, They are secreted by $S$. aureusenterotoxins, six antigenic types have been found in this catigory (named SE-A, B, C, D, E and G), and toxic shock syndrome toxin (TSST-1) (Schlievert et al., 2000). These enterotoxins after ingested with food induce diarrhea and vomiting and are responsible for staphylococcal food poisoning.TSST-1 has a systemic effect and is the main cause of toxic shock syndrome (TSS); in addition, enterotoxins also can induce toxic shock syndrome.However, nasal colonization increases the risk of infection byfour-fold (Safdar \& Bradley, 2008).

Forroutine detection of superantigens, commercially produced kits, such as reverse passive latex agglutination assays and enzymelinked immunosorbent assays, were most commonly used. However, these methods were to date designed only to detect limited types of superantigens. As an alternative to these more traditional methods, the PCR approach can provide detection of toxin genes and is presently designed to detect the majority of (SAg) (McLauchlin et al., 2001).However, a gene's presence does not establish its enterotoxigenic properties of a strain therefore, the expression of the gene should also be evaluated (Fooladiet al, 2010)

\section{Material and Method}

The study was included two groups:

The first group (patients group): This group included 100 patients with Allergic rhinitis. These patients attended Al-Sadder Medical City, an outpatient clinic of ENT in Najaf city during the period from March 2014 to November 2014.

Exclusion criteria; 
1. Patients who received antibiotics or oral corticosteroid therapy or had upper respiratory infections during the four weeks before enrollment.

2. Patients who already started or completed immunotherapy.

The control groups consist of 100 non allergic healthy volunteers not suffering from respiratory symptoms for isolation of S.aureus, a nasal swab was taken from each of the 100 patients

\section{Isolation and Identification of $S$. aureus}

Specimens were taken via the insertion of a sterile moistened swab in both nostrils to a depth of approximately $1 \mathrm{~cm}$ into the nostril and rotated five times. After collection, specimens were immediately transported to the lab for inoculation on the culture medium. Samples were directly inoculated onto mannitol salt agar, Chromoagar plates and incubated at $37^{\circ} \mathrm{C}$ for 24 hours. $S$. aureus isolate identification was based on morphology, Gram's stain property, coagulase test, catalase test and mannitol salt agar fermentation.

\section{Biomerieux Vitek 2 Compact Automated Microbial Identification}

Automated VITEK® 2 ID cards this technique isused in order to provide reliable, accurate results for isolated bacteria.

\section{DNA Extraction}

According to Mini gDNA Bacteria Kit protocol (Geneaid Biotech Ltd)

\section{Polymerase Chain Reaction Protocols}

Programs for PCR thermocycling conditions for detection of virulencegenes

\begin{tabular}{|c|c|c|c|c|c|c|}
\hline \multirow{3}{*}{$\begin{array}{l}\text { MONOPL } \\
\text { EX GENE }\end{array}$} & \multicolumn{5}{|c|}{ " TEMPERATURE $\left({ }^{\circ} \mathrm{C}\right) /$ TIME } & \multirow{3}{*}{$\begin{array}{c}\text { CYCLE } \\
\text { NUMBER }\end{array}$} \\
\hline & \multirow{2}{*}{$\begin{array}{c}\text { Initial } \\
\text { denaturation }\end{array}$} & \multicolumn{3}{|c|}{ Cycling condition } & \multirow{2}{*}{$\begin{array}{c}\text { Final } \\
\text { extension }\end{array}$} & \\
\hline & & Denaturation & Annealing & Extension & & \\
\hline Sea & $94^{\circ} / 5 \min$ & $94^{\circ} / 2 \min$ & $57^{\circ} / 2 \min$ & $72^{\circ} / 1 \min$ & $72^{\circ} / 7 \mathrm{~min}$ & 35 \\
\hline $\mathrm{Seb}$ & $94^{\circ} / 5 \mathrm{~min}$ & $94^{\circ} / 2 \min$ & $57^{\circ} / 2 \min$ & $72 \% 1 \mathrm{~min}$ & $72^{\circ} / 7 \mathrm{~min}$ & 35 \\
\hline $\mathrm{Sec}$ & $94^{\circ} / 5 \mathrm{~min}$ & $94^{\circ} / 2 \min$ & $57^{\circ} / 2 \min$ & $72^{\circ} / 1 \mathrm{~min}$ & $72^{\circ} / 7 \mathrm{~min}$ & 35 \\
\hline Sed & $94^{\circ} / 5 \mathrm{~min}$ & $94^{\circ} / 2 \min$ & $57^{\circ} / 2 \min$ & $72^{\circ} / 1 \min$ & $72^{\circ} / 7 \mathrm{~min}$ & 35 \\
\hline See & $94^{\circ} / 5 \mathrm{~min}$ & $94^{\circ} / 2 \min$ & $57^{\circ} / 2 \min$ & $72 \% / 1 \mathrm{~min}$ & $72^{\circ} / 7 \mathrm{~min}$ & 35 \\
\hline Tsst & $94^{\circ} / 5 \mathrm{~min}$ & $94^{\circ} / 2 \min$ & $57^{\circ} / 2 \min$ & $72 \% / 1 \min$ & $72^{\circ} / 7 \mathrm{~min}$ & 35 \\
\hline
\end{tabular}

\section{Preparing the Primers Suspension}

The DNA primers were suspendedby addition the lyophilized product after spinning down briefly with TE buffer molecular grad depending on manufacturer instruction as stock suspension. Working primer tube was prepared by diluted with TE buffer molecular grad. The final picomoles depended on the procedure of each primer

Enzyme immunoassay for identifying of Staphylococcus enterotoxins $A, B, C, D$ and $E$ in cultures
Is a sandwich enzyme immunoassay for identification of Staphylococcus enterotoxins,all Staphylococcus aureus bacteria were examined in each allergic patient and each control subject. after preliminary growth on the agar plates, Staphylococcus aureus cultured were transferred to brain heart infusion BHI broth and cultured aerobically at $37^{\circ} \mathrm{C}$,centrifuged supernatants of microbiological fluid cultures $5 \mathrm{~min} /$ at a minimum of $3500 \mathrm{~g} / 10^{\circ} \mathrm{C}$ sterile filtration of the supernatant is strongly advisable as any precipitated or resuspended cells may influence the test reaction , 
the ability of bacteria to produced toxin was

RIDASCREEN ® SET A, B,C,D,E. measured by enzyme immune assay

\section{Primers forMonoplex PCR}

\begin{tabular}{|c|c|c|c|c|c|}
\hline TYPE & $\begin{array}{r}\text { PRIMER } \\
\text { NAME }\end{array}$ & OLIGO SEQUENCE (3'-5') & $\begin{array}{r}\text { PRODUCT } \\
\text { SIZE (BP) }\end{array}$ & REFERENCE & ORIGIN \\
\hline \multirow{6}{*}{ 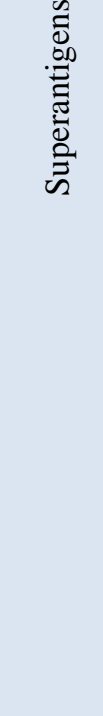 } & sea & $\begin{array}{l}\text { F: GGTTATCAATGTGCGGGTGG } \\
\text { R: CGGCACTTTTTTCTCTTCGG }\end{array}$ & 102 & Mehrotra et al.,2000 & Korea \\
\hline & seb & $\begin{array}{l}\text { F:GTATGGTGGTGTAACTGAGC } \\
\text { R:CCAAATAGTGACGAGTTAGG }\end{array}$ & 164 & Mehrotra et al.,2000 & Korea \\
\hline & $\sec$ & $\begin{array}{l}\text { F:AGATGAAGTAGTTGATGTGTATGG } \\
\text { R:CACACTTTTAGAATCAACCG }\end{array}$ & 451 & Mehrotra et al.,2000 & Korea \\
\hline & sed & $\begin{array}{r}\text { F:CCAATAATAGGAGAAAATAAAAG } \\
\text { R:ATTGGTATTTTTTTTCGTTC }\end{array}$ & 278 & Mehrotra et a.,2000 & Korea \\
\hline & see & $\begin{array}{r}\text { F:AGGTTTTTTCACAGGTCATCC } \\
\text { R:CTTTTTTTTCTTCGGTCAATC }\end{array}$ & 209 & Mehrotra et al.,2000 & Korea \\
\hline & tst & $\begin{array}{l}\text { F:ACCCCTGTTCCCTTATCATC } \\
\text { R:TTTTCAGTATTTGTAACGCC }\end{array}$ & 326 & Mehrotra et al.,2000 & Korea \\
\hline
\end{tabular}

\section{Result}

Table (1) Total studied patients with allergic rhinitis and control included in the study

\begin{tabular}{|c|c|c|c|c|c|c||}
\hline Study groups & NO & $\begin{array}{c}\text { Positive for } \\
\text { S.aureus }\end{array}$ & $\%$ & $\begin{array}{c}\text { Negative for } \\
\text { S.aureus }\end{array}$ & $\%$ & P value \\
\hline $\begin{array}{c}\text { Allergic rhinitis } \\
\text { patients }\end{array}$ & 100 & 52 & $52 \%$ & 48 & $48.0 \%$ & $<0.001$ \\
\hline control & 100 & 24 & $24.0 \%$ & 76 & $76 \%$ & $\begin{array}{c}\text { Odds=3.4306 } \\
\text { CI=1.8-6.26 }\end{array}$ \\
\hline Total & 200 & 76 & $38 \%$ & 124 & $62 \%$ & \\
\hline
\end{tabular}

Table (2) show the distribution of toxigenic and non- toxigenic of S. aureus isolates recovered from allergic rhinitis patients and control by PCR

\begin{tabular}{||l|c|c|c|c|c|c||}
\hline \hline & $\begin{array}{c}\text { S.AUREUS } \\
\text { ISOLATED FROM } \\
\text { PATIENTS GROUP }\end{array}$ & $\%$ & $\begin{array}{c}\text { S.AUREUS } \\
\text { ISOLATED FROM } \\
\text { CONTROL GROUP }\end{array}$ & $\%$ & TOTAL & $\%$ \\
\hline \hline toxigenic & 48 & $63.16 \%$ & 20 & $26.32 \%$ & 68 & $89.48 \%$ \\
\hline $\begin{array}{l}\text { Non } \\
\text { toxigenic }\end{array}$ & 4 & $5.26 \%$ & 4 & $5.26 \%$ & 8 & $10.52 \%$ \\
\hline Total & 52 & $68.42 \%$ & 24 & $31.58 \%$ & 76 & $100 \%$ \\
\hline
\end{tabular}

P-value $=0.434$ 
Table (3) show the distribution of superantigens among (76 S. aureus) isolates recovered from allergic rhinitis patients and control by both PCR and Elisa test

\begin{tabular}{||c|c|c|c|c|c|c||}
\hline \hline ENTEROTOXIN & PCR & $100 \%$ & ELISA & $100 \%$ & SENSITIVITY & SPECIFICITY \\
\hline SEA & 52 & 68.42 & 16 & 21.052 & $23.1 \%$ & $83.3 \%$ \\
\hline SEB & 64 & 84.21 & 8 & 10.53 & $12.5 \%$ & $100 \%$ \\
\hline SEE & 16 & 21.05 & 12 & 15.79 & $100 \%$ & $100 \%$ \\
\hline SEC & 8 & 10.53 & 8 & 10.53 & $100 \%$ & $100 \%$ \\
\hline SED & 8 & 10.53 & 8 & 10.53 & $100 \%$ & $100 \%$ \\
\hline TSST & 0 & 0 & 0 & 0 & 0 & 0 \\
\hline
\end{tabular}

Table (4) distribution of superantiens genes among toxigenic $S$ aureus in AR patients and control groups

\begin{tabular}{||c|c|c|c|c|c|c|c|c|c||}
\hline \hline & $\begin{array}{c}S \\
\text { AUREUS }\end{array}$ & $\begin{array}{c}\text { ONE } \\
\text { TYPE OF } \\
\text { TOXIN }\end{array}$ & $100 \%$ & $\begin{array}{c}\text { TWOTY } \\
\text { PE OF } \\
\text { TOXIN }\end{array}$ & $100 \%$ & $\begin{array}{c}\text { THREE } \\
\text { TYPE } \\
\text { OF } \\
\text { TOXIN }\end{array}$ & $100 \%$ & $\begin{array}{c}\text { FOUR } \\
\text { TYPE OF } \\
\text { TOXIN }\end{array}$ & $100 \%$ \\
\hline Patients & 48 & 8 & $16.67 \%$ & 32 & $66.66 \%$ & 8 & $16.67 \%$ & 4 & $8.33 \%$ \\
\hline Control & 20 & 8 & $40 \%$ & 8 & $40 \%$ & 4 & $20 \%$ & 0 & 0 \\
\hline Total & 68 & 16 & $56.67 \%$ & 40 & $106.66 \%$ & 12 & $36.67 \%$ & 4 & $8.33 \%$ \\
\hline
\end{tabular}

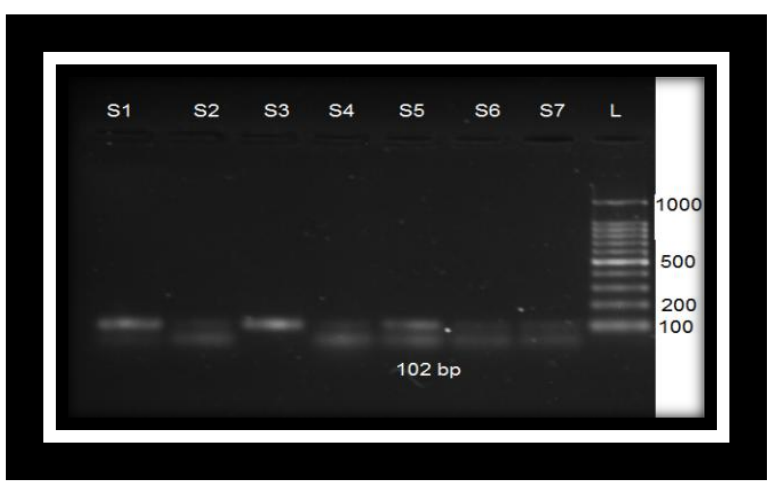

Figure (1.): Ethidium bromide-stained agarose gel of PCR, amplified products from extracted DNA of $S$. aureusisolates and amplified with forward and reverse primer sea. The electrophoresis was performed at 70 volt for $1.5 \mathrm{hr}$. Lane (L) DNA molecular size marker (1000 bp ladder), Lanes (1, 2, 3, 4, 5,6 and 7) shows positive results with sea gene (102 bp).

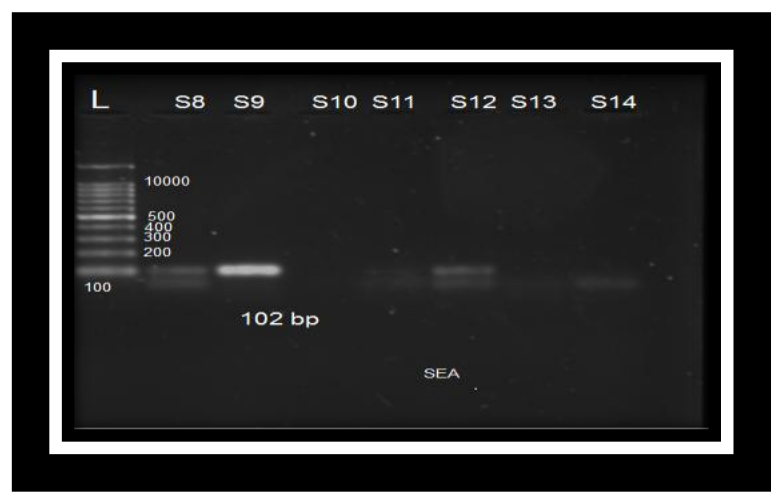

Figure (2.): Ethidium bromide-stained agarose gel of PCR, amplified products from extracted DNA of $S$. aureusisolates and amplified with forward and reverse primer sea. The electrophoresis was performed at 70 volt for $1.5 \mathrm{hr}$. Lane (L) DNA molecular size marker (1000 bp ladder), Lanes $(8,9,12$ and 14) shows positive results with sea gene (102 bp) Lanes (S10, 11, and 13) show negative results with sea gene.

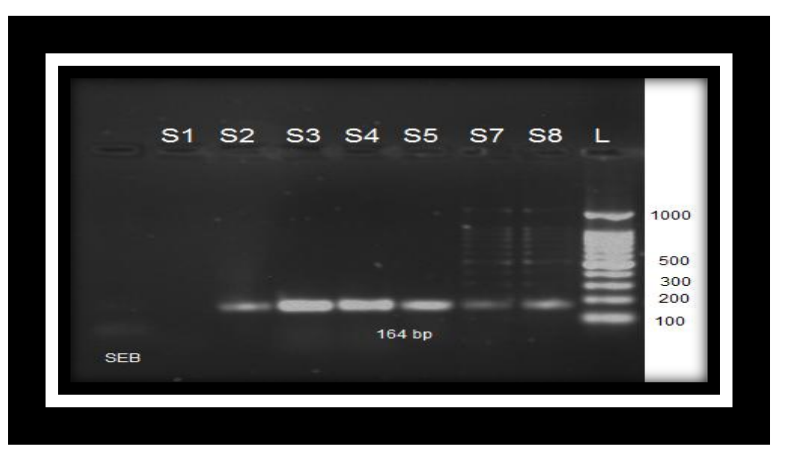

Figure (3): Ethidium bromide-stained agarose gel of PCR, amplified products from extracted DNA of $S$. aureusisolates and amplified with forward and reverse primer seb. The electrophoresis was performed at 70 volt for $1.5 \mathrm{hr}$. Lane (L) DNA molecular size marker (1000 bp ladder), Lanes (S2,3,4,5,7 and 8) shows positive results with seb gene (164 bp), Lanes (1 ) show negative result with seb gene 


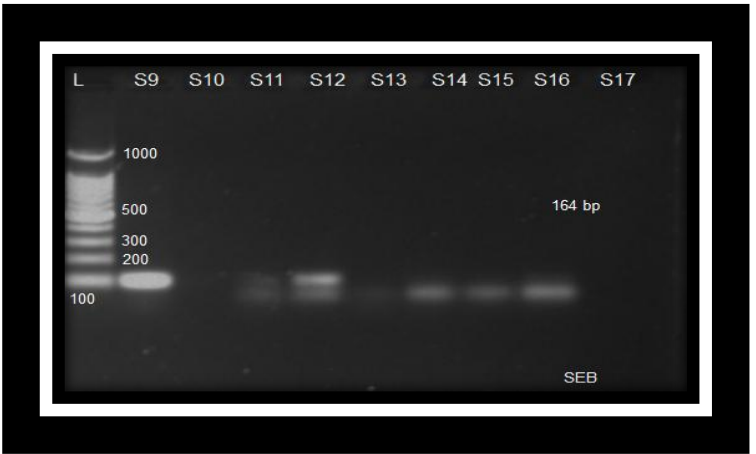

Figure (4): Ethidium bromide-stained agarose gel of PCR, amplified products from extracted DNA of $S$. aureusisolates and amplified with forward and reverse primer seb. The electrophoresis was performed at 70 volt for $1.5 \mathrm{hr}$. Lane (L) DNA molecular size marker (1000 bp ladder), Lanes (S9,11,12,14, and 16) shows positive results with seb gene (164 bp), Lanes (10,13 and 17 ) show negative result with $s e b$ gene.

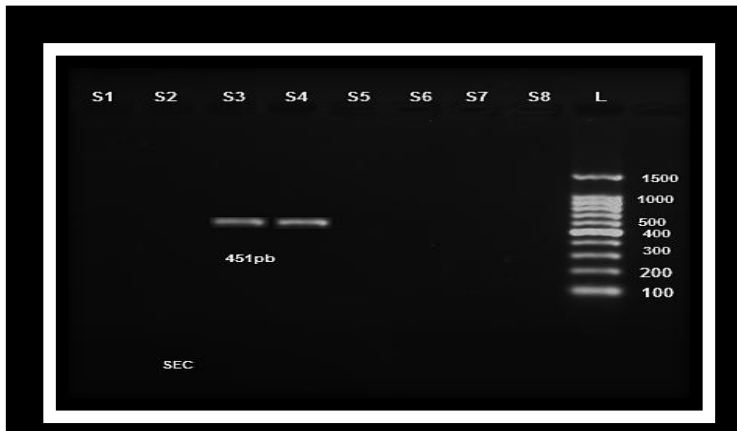

Figure (5): Ethidium bromide-stained agarose gel of PC R, amplifiedproducts from extracted DNA of $S$. aureusisolates and amplified with forward and reverse primer sec. The electrophoresis was performe d at 70 volt for $1.5 \mathrm{hr}$. Lane (L) DNA molecular size marker (1000 bp ladder), Lanes (S 3 and 4) shows positive results with sec gene (451 bp), Lanes (1,2,5,6,7 and 8 ) show negative results with $\sec$ gene.

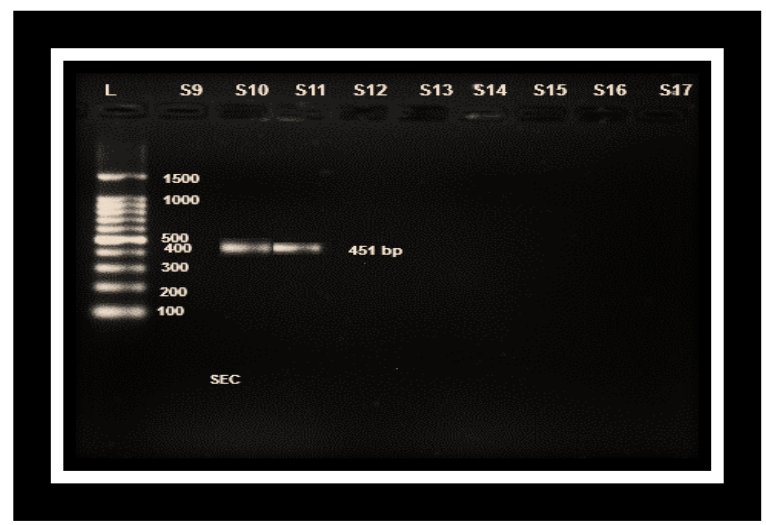

Figure (6): Ethidium bromide-stained agarose gel of PCR, amplified products from extracted DNA of $S$. aureusisolates and amplified with forward and reverse primer sec. The electrophoresis was performed at 70 volt for $1.5 \mathrm{hr}$. Lane (L) DNA molecular size marker (1000 bp ladder), Lanes (S 10and 11) shows positive results with sec gene (451 bp), Lanes $(9,2,13,14,15,16$, and 17 ) show negative results with $\mathrm{sec}$ gene.

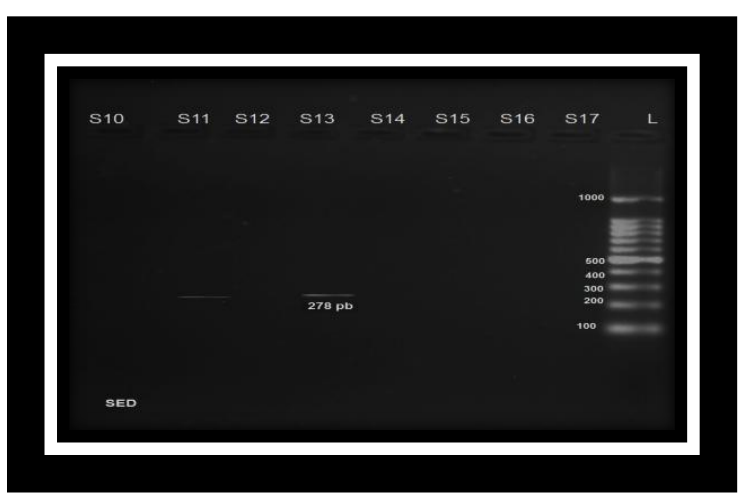

Figure (7): Ethidium bromide-stained agarose gel of PCR, amplified products from extracted DNA of $S$. aureusisolates and amplified with forward and reverse primer sed. The electrophoresis was performed at 70 volt for $1.5 \mathrm{hr}$. Lane (L) DNA molecular size marker (1000 bp ladder), Lanes ( $\mathrm{S}$ 11 and 13) shows positive results with sed gene (278 bp), Lanes (S10,12,14,15,16 and 17 ) show negative results with sedgene

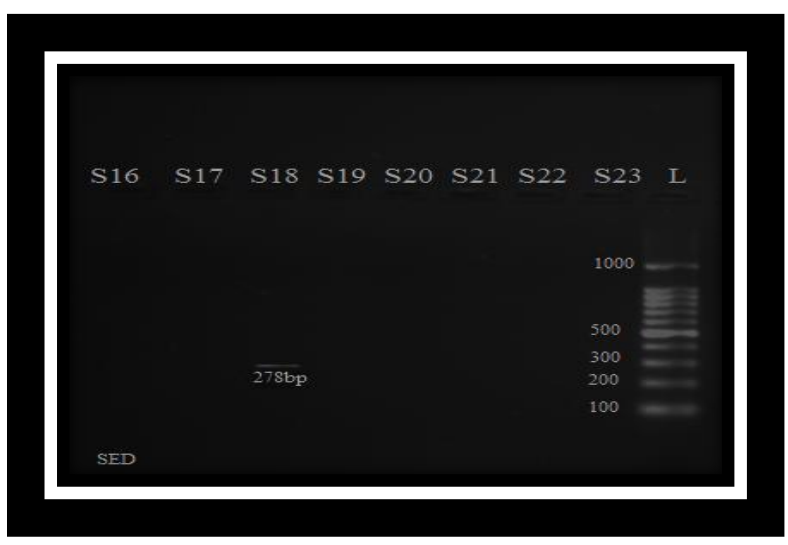

Figure (8): Ethidium bromide-stained agarose gel of P CR, amplified products from extracted DNA of $S$. aureus isolates and amplified with forward and reverse primer sed. The electrophoresis was performed at 70 volt for $1.5 \mathrm{hr}$. Lane (L) DNA molecular size marker (1000 bp ladder), Lanes (S 
18) shows positive results with sed gene (278 bp), Lanes $(16,17,19,20,21,22$, and 23 ) show negative results with sed gene

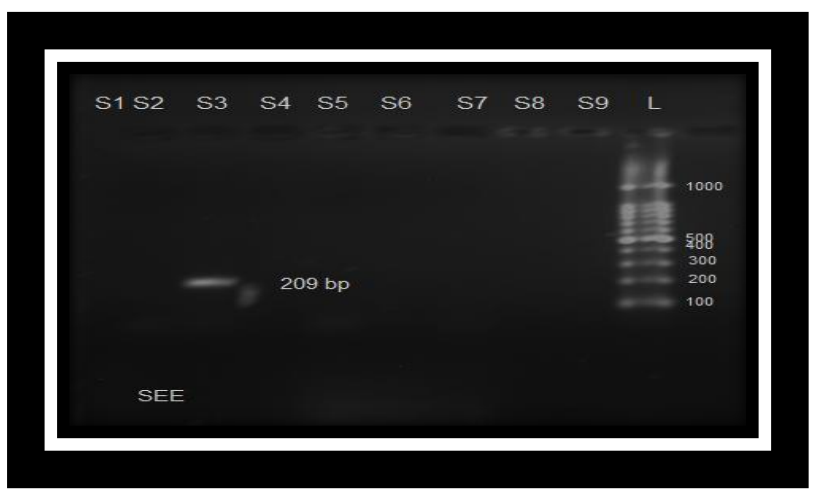

Figure (9): Ethidium bromide-stained agarose gel of PCR, amplified products from extracted DNA of $S$. aureus isolates and amplified with forward and reverse primer see. The electrophoresis was performed at 70 volt for $1.5 \mathrm{hr}$. Lane (L) DNA molecular size marker (1000 bp ladder), Lanes (S 3) shows positive results with see gene (209 bp), Lanes(1,2,4,5,6,7,8 and 9 ) show negative results with see gene

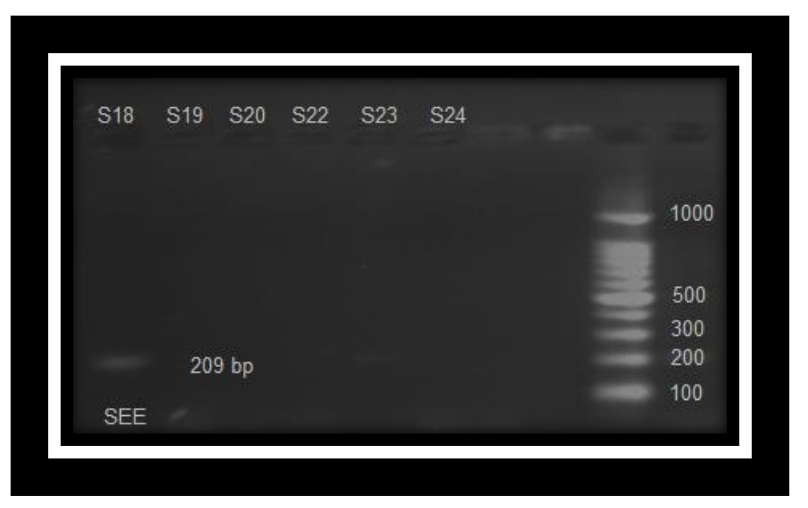

Figure (10): Ethidium bromide-stained agarose gel of PCR, amplified products from extracted DNA of $S$. aureus isolates and amplified with forward and reverse primer see. The electrophoresis was performed at 70 volt for $1.5 \mathrm{hr}$. Lane (L) DNA molecular size marker (1000 bp ladder), Lanes (S 18) shows positive results with see gene (209 bp), Lanes (19,20,22,23 and 24 ) show negative results with see gene

\section{Discussion}

\section{The carriage rate of $S$ aureus in nasal cavity:}

It was focused in table (1) regarded the rate of isolation of $S$. aureus from the nasal cavity of patients with allergic rhinitis (AR) in comparison to that of nasal cavity of control subjects (not allergic subject) it was seen from the table that $52(52 \%)$ of the nasal swab from patients with allergic rhinitis (AR) showed growth of $S$. aureus in comparison to $24(24 \%)$ of the swab that was taken from the nasal cavity of control subject, the difference between the two results was shown to be significant $\mathrm{P}<0.001$, Odds 3.43306 .

The patients with allergic rhinitis showed to be higher carriers of $S$. aureus in their noses.The result of this table is in agreement with (Shiomori et al.,2000)

\section{Superantigenic exotoxins produced by $\boldsymbol{S}$ aureus}

Staphylococcus aureus (SA) is one of the most common human bacterial pathogens and produces enterotoxins that act as toxins and superantigens. Staphylococcal enterotoxins are a family of structurally related proteins comprised of different serological types: Staphylococcus enterotoxins A (SEA), B (SEB), C, D, E (up to U), and toxic shock syndrome toxin-1 (TSST-1). (Bachert et $a l ., 2007)$ the stimulatory role of superantigens in the development of inflammation in chronic rhinosinusitis and nasal polyposis has been documented. It has been postulated that SA and its products are related to the pathogenesis of allergic inflammatory diseases, including rhinitis and atopic dermatitis (Bachert et al., 2010; Ikezawa et al., 2010; Liu et al., 2014).There has recently been much interest in the role of bacterial superantigens in allergic inflammatory reactions. Numerous studies have demonstrated that bacterial superantigens regulate the activity of immunomodulatory ( $\mathrm{T}$ lymphocytes) and proinflammatory cell types (dendritic cells, eosinophils and epithelial cells etc), and play an important role on allergic disease.

Mechanistic studies have shown that superantigens stimulate the $\mathrm{T}$ cells by crosslinking the variable part on the beta chain of the T-cell receptor (TCR) with MHC class II 
molecules outside the peptide-binding groove area. This leads to stimulation of up to $30 \%$ of the naive $\mathrm{T}$-cell population in a nonspecific way, compared with stimulation of only about $0.1 \%$ of the $\mathrm{T}$ cell population via the conventional allergen-specific MHC-restricted route utilizing both TCR-Va and $b$ chains. Thus, direct binding of SEB to an MHC class II molecule loaded with antigen-derived peptides might enhance the antigenicity of the allergen and the development of allergic disease. In addition, SEB may act as allergens. SEB can induce antigen-specific $\mathrm{T}$ cells that are able to promote the generation of antigenspecific IgE antibodies, which subsequently play a role in'conventional'allergen-mediated reactions. Humans are natural carriers for staphylococcus aureus, the nasal passage and skin being the most common site for staphylococcus aureus colonization.(Jusufagicet al .,2006; Tang., 2012)

The destination of this study was to evaluate the frequency of genes that code for superantigens including enterotoxins through $\mathrm{A}, \mathrm{B}, \mathrm{CD}, \mathrm{E}$ and toxic shock syndrome toxin (TSST) in S. aureus isolates recovered from allergic rhinitis patients, all (76)S. aureusisolates diagnostic positive were applied for toxin gene distribution analysis. Sequences specific for staphylococcal toxin genes were detected by PCR.

In the present study, monoplex PCR assay was designed to detect toxin genes employed here

Table (2) shows that, (63.16\%) of S.aureus isolated strains from AR patients were producing one or more enterotoxins, whereas $(26.32 \%)$ of S.aureus from the control subjects produced detectable enterotoxins the difference nonsignificant $(\mathrm{p}=0.434)$, and $S$. aureus non toxigenic isolated in equal number in $\mathrm{AR}$ patients and control group (5.26\%), Our finding were in agreement with those of (Azzazy et al.,2015) who reported thatthe frequency of nasal carriage of $S$. aureusin the patients group was 25/45 (55.56\%), while in control group was $6 / 45(13.33 \%)$ with highly significant difference $\left(\chi^{2}=17.8\right.$ and $P_{-}$ 0.001).
The results of molecular investigations for the finding of genes ncoding the toxins; SEA, SEB, SEC, SED, SEE and TSST.

In table no (3) show the distribution of superantigens among (76 S. aureus) isolates recovered from allergic rhinitis patients and control by both PCR and Elisa test $S$. Aureus containing enterotoxins were $(84.21 \%)$ for SEB, (68.42\%)for SEA,( $21.05 \%)$ for SEE, $(10.53 \%)$ for SED, (10.53\%) for SEC and (0\%) for TSST in patients by PCR method As noticed, the most frequently detected enterotoxin was staphylococcal enterotoxin B (SEB).

While by ELISA method we found that the main type of toxin was SEA (21.052\%), SEB $(10.526 \%)$, SEC (10.526\%), SED (10.526\%), TSST (0) and SEE (15.789\%).

While in case of PCR results for gene detection the present results was also not much different from that seen by (Shiomori et al.,2000) who found that the rates of culture supernatants containing the individual superantigenic exotoxins were $13 \%$ for SEA, $54 \%$ for SEB, and the rate of SEB was the highest among the enterotoxins, the result was similar with little difference especially in TSST, which was $20 \%$ in case of Shiomori study and $0 \%$ in the present study, but it was the same as in case of (Azzazy et al .,2015) who found that TSST toxin gene was $0 \%$ both in case of PCR , and also when ELISA detection was performed ,he also found that SEB toxin was higher than other enterotoxin a result which was slightly different from the present study in which SEA was found to be the highest. The most frequent enterotoxin type was type B(PALA et al., 2010).

ELISA test seem to be more sensitive for (SED, SEC, and SEE) and less sensitive for (SEA and SEB), however the specificity of ELISA is better in (SEB, SEC, SED, SEE than SEA.

However, a possible limitation of this procedure is that the molecular methods are only able to demonstrate the existence of the genes encoding for SEs in bacteria but cannot prove that production of SEs protein occurs unless RT-PCR is carried out (Morandi et al., 2007). High 
percentages of $S$. aureuswith enterotoxin genes, especially SEA, were confirmed phenotypically and the results of PCR showed a clear relationship with immune assay results, this was in agreement with other previous study as (Anvari et al., 2008). Nevertheless, with regard to SEB, more differences are observed between genotypical and phenotypical methods (Fooladi et al., 2010).

\section{Distribution of enterotoxin genes in toxigenic $S$ aureus in patients and control groups}

Table (4) show the distribution of enterotoxin genes in toxigenic $S$ aureus in patients and control groups toxigenic S.aureus that produced one type of toxin isolated from patients and control group from 16 strains $(56.67 \%)$, S.aureus that produced two type of toxin isolated from 40 isolated strain $(106.66 \%)$ S.aureus that produced three type of toxin isolated from 12isolated strain (36.67\%) and S.aureus that produced fore type of toxin isolated from 4isolated strain $(8.33 \%)$, In fact when a revision of the results of this table was done, we could found that the bacterial isolates which excreted 2 type of enterotoxin was higher than that which excreted either one type or 3,4 type of the enterotoxins, at the same time there were a scanty of studies which explained or demonstrated the combined existence of enterotoxigenic both in case of molecular studies or in ELISA studies.

Conclusion we have demonstrated that the rate of nasal carriage of Staphylococcus aureus in allergic rhinitis patients was significantly higher than that of control subject,-Staphylococcus aureus isolated from allergic rhinitis patients have a probably a relationship with the disease and their superantigen have been arole in triggering and exacerbation of the disease

\section{References}

1. Liu ,Jing., Nan, Young-Min., Ye, DongHo., Nahmand, Hae-Sim. Park 2014 The Prevalence of Serum Specific IgE to Superantigens in Asthma and Allergic Rhinitis Patients y Asthma Immunol Res. 6(3):263-266.
2. Al-Abri, R,.Bharghava, D,.Kurien ,.M, Chaly, V,. Al-Badaai ,Y,. Bharghava ,K.( 2014) Allergic rhinitis and associated comorbidities: prevalence in oman with knowledge gaps in literature.Oman Med J.;29 (6):414-8.

3. Guilemany, J.M., 2009. Persistent allergic rhinitis has a moderate impact on the sense of smell, depending on both nasal congestion and inflammation .Laryngoscope, 119(2): p. 233-8.

4. Rondón,C., Romero, JJ., Lopez, S., Antúnez, C., Martín-Casañez E, Torres, MJ., ayorga ,C., R-Pena, R., Blanca, M.( 2007)Local IgEproductionand positive nasal provocation test in patients with persistent nonallergic rhinitis. J Allergy Clin Immunol;119:899-905.

5. Murray, P., Baron, E., Jorgensen, J., Pfaller, M. and Yole, R. (2003).Manual of clinical Microbiology. $8^{\text {th }}$ ed., American Society for Clinical Microbiology, Washington, DC., 1: 57-61.

6. Liu ,Z,. Albanese ,E., Li, S., Huang ,Y., Ferri, CP., Yan ,F., et al. (2009) Chronic disease prevalence and care among the elderly in urban and rural Beijing, China a 10/66 Dementia Research Group crosssectional survey. BMC Public Health;9:394

7. Chambers ,H, F and F, R, DeLeo. (2009). Waves of resistance: Staphylococcus aureusin the antibiotic era, Nature Reviews Microbiology, vol. 7, no. 9, pp. 629-641

8. Lowy, FD. (1998) Staphylococcus aureus infections, The New England Journal of Medicine, vol. 339, pp. 520-532.

9. Daum, R.S. (2007). Skin and soft tissue infections caused by methicilin - resist and Staphylococcus aureus .New England Journal of medicine 357:380-390.

10. Safdar,N ., and Bradley,E,A.(2008). The risk of infection after nasal col- onization with Staphylococcus aureus.Am.J.Med. 121, 310-315. 
11. Schlievert,P.,M.,Jablonski,L.M., Roggiani, M., Sadler,I.,Callantine, S., Mitchell ,D.T., Ohlendorf, D. H, and Bohach,G.A. (2000). Pyrogenic toxin superantigensite specificity in toxic shock syndrome and food poisoning inanimals.Infect.Immun. 68, 3630-3634.

12. Shiomori ,Teruo., MD,A Shin-ichi., Yoshida, MD., Hiroshi, Miyamoto, MD.(2000) Relationship of nasal carriage of Staphylococcus aureusto thogenesis of perennial allergic rhinitis $\mathrm{j}$ allergy clinimmunol .450-454

13. Bachert,C, P., Gevaert, P., Van, Cauwenberge .Staphylococcus aureus enterotoxins.(2002): a key in airway disease? Allergy: 57: 480-487.

14. Bachert, C.,Zhang,N.,Holtappels, G., DeLobel, L., Van Cauwenberge, P., Liu,S.,Lin ,P., Bousquet,J., and VanSteen ,K. (2010).Presenceof IL-5proteinand IgE antibodies to staphylococcal enterotoxins in nasal polyps is associated with comorbid asthma. J. Allergy Clin. I mmunol.126, 962-968,968e961 -966.

15. Ikezawa, Z., Komori „J., Ikezawa, Y., Inoue, Y., Kirino, M., Katsuyama ,M., Aihara, M.(2010) A role of Staphyococcus aureus, interleukin-18, nerve growth factor and semaphorin 3A, an axon guidance molecule, in pathogenesis and treatment of atopic dermatitis. Allergy Asthma Immunol Res.;2:235-246.

16. Liu ,Jing., Nan, Young-Min., Ye, DongHo., Nahmand, Hae-Sim,Park .(2014) The Prevalence of Serum Specific IgE to Superantigens in Asthma and Allergic Rhinitis Patients y Asthma Immunol Res. 6(3):263-266

17. Tang, X.Y. 2012 Effects Of Staphylococcal Enterotoxin B In The Pathogenesis Of Allergic Rhinitis Dissertation

18. Bachert C, Gevaert P, Zhang N, van Zele T, Perez-Novo C.(2007) Role of staphylo- coccal superantigens in airway disease. ChemImmunol Allergy;93:214-236.

19. Azzazy , Ensaf ,A., Hossam, A., Aziz, Maha K. Gohar, Reham H. Anis 2015 Nasal Carriage of Superantigen Producing Staphylococcus Aureus and Its Role in Pathogenesis of Allergic Rhinitis and Bronchial Asthma Egyptian Journal of Medical Microbiology Vol 24 /No. 4 / Oct.

20. Mclauchlan, A.; Ogbonnaya, F.C.; Hollingsworth, B.; CarTer, M.; Gale, K.R.; Henry, R.J.; Holton, T.A.; Morell, M.K.; Rampling, L.R.; Sharp, P.J.; Shariflou, M.R.; Jones, M.G.K. And Appels, R. (, 2001)Development of robust PCR-based DNA markers for each homoeo-allele of granule-bound starch synthase and their application in wheat breeding programs. Australian Journal ofAgriculture Research, vol. 52, no. 11-12, p. 1409-1416.

21. Fooladi,Imani., A, Tavakoli., HR2, Naderi. ( 2010) Detection of enterotoxigenic Staphylococcus aureusisolates in domestic dairy products Iranian jornal of microbiology Vol 2 No 3 (Sept) 135-140.

22. PALA , Kayıhan., Cüneyt, ÖZAKIN., Nalan ,AKIŞ., Melda ,Sinirtaş., Suna, gedikoğlu., hamdi, aytekin.(2010) Asymptomatic carriage of bacteria in food workers in Nilüfer district, Bursa, Turkey Turk J Med Sci 2010; 40 (1): 133-139

23. Morandi L, de Biase D, Visani M, Cesari V, De Maglio G, Pizzolitto S, Pession A, Tallini G.(2012) Allele Specific Locked Nucleic Acid Quantitative PCR (ASLNAqPCR): an accurate and costeffective assay to diagnose and quantify KRAS and BRAF mutation. PLoS One.;7:e36084. doi: 10.1371/ journal. pone. 0036084

24. Anvari SH, Sattari M, Forozandehe Moghadam M, (2008).NajarPeerayeh SH,Imanee Fouladi AA. Detection of Staphylococcus aureus Enterotoxins A to E from clinical samples by PCR. Res J of BioloScie; 3 (8): 826-829. 
25. Morandi S, Brasca M, Lodi R, Cremonesi P, Castiglioni B.( 2007) Detection of classical enterotoxins and identification of enterotoxin genes in Staphylococcus aureusfrom milk and dairy products. VeterMicrobiol; 124: 66-72.

26. Mehrotra ,M., Wang,G., Johnson ,WM. 2000Multiplex PCR for detection of genes for Staphylococcus aureus enterotoxins, exfoliative toxins, toxic shock syndrome toxin 1, and methicillin resistance.J ClinMicrobiol. Mar;38(3):1032-5. 